\title{
GENETIC PARAMETERS FOR SOME YIELD AND YIELD COMPONENTS CHARACTERS IN FOUR CROSSES OF BREAD WHEAT UNDER TWO WATER REGIME TREATMENTS \\ Sultan, M. S. ${ }^{1}$; A. H. Abd El-Latif ${ }^{2}$; M. A. Abdel-Moneam ${ }^{1}$ and M. N. A. El-Hawary ${ }^{2}$ \\ 1- Agron. Dept., Fac. Agric. Mansoura University, Egypt. \\ 2- Wheat Research Dept., Field Crops Research Institute, ARC. Egypt.
}

\begin{abstract}
Six populations; $P_{1}, P_{2}, F_{1}, F_{2}, B_{1}$ and $B_{2}$ of four bread wheat crosses were used in this study to determine quantitative genetic parameters for yield and its components characters under normal and water stress treatments. The means of the six generations were recorded for plant height, spikes number plant ${ }^{-1}$, grains number spike $^{-1}, 100$-grain weight and grain yield plant $^{-1}$ in four crosses namely; Line $1 \times$ Sakha 93, Line 1×Sakha 94 , Sakha 93×Gemmiza 9 and Sakha $94 \times$ Gemmiza 9 generated from four diverse parents. The experiment was carried out in 2006/2007 to 2008/2009 seasons at Sakha Agric. Res. Station, ARC. The means of the four crosses significantly decreased under the water stress treatments for yield and its components characters as the effect of water stress at most cases. The T-test of differences between parents of each cross under each treatment showed highly significant values in most cases in the four studied crosses under both treatments. The results showed the importance of additive gene effects in the inheritance of plant height and spikes number plant ${ }^{-1}$, while, additive, dominance and epistasis were the important in the inheritance of grains number spike ${ }^{-1}, 100$-grain weight and grain yield plant $^{-1}$ at most cases under both normal and water stress treatments. Moreover additive genetic variance played the greatest and the important role in the inheritance of plant height, spikes number plant ${ }^{-1}$ and grain yield plant ${ }^{-1}$ at most cases under both water treatments. On the other hand, dominance genetic variance was the greatest and the important in the inheritance of grains number spike ${ }^{-1}$ and 100 -grain weight at most cases under both water treatments. On the other side, heritability in broad sense had medium to high percentages for all studied characters at all cases under normal and water stress treatments. Meanwhile, heritability in narrow sense had moderate to high values for yield and yield components characters at most cases under both water treatments, except grains number spike ${ }^{-1}$ which had low values at most cases under both water treatments. Genetic advance under selection was low for plant height at most cases under both water treatments. While, it was high for spikes number plant ${ }^{-1}$ and grain yield plant $^{-1}$ at most cases under both water treatments. Also, it was founded to be low to high for plant height, grains number spike ${ }^{-1}$ and 100-grain weight at most cases under both water treatments.
\end{abstract}

Keywords: Bread wheat, water stress, Generation mean analysis, Gene action, components of variances, Heritability,

\section{INTRODUCTION}

Increasing wheat production under certain abiotic stress condition, i.e. drought stress, has become important during recent years, since wheat production in these areas with optimum growth conditions does not meet the needs of over increasing population of Egypt. Drought or water stress can be 
defined as the absence of rainfall or irrigation for a period of time sufficient to deplete soil moisture and injure plants. Drought resistance is defined by Hall (1993) as the relative yield of a genotype compared to other genotypes subjected to the same drought stress. On the other hand, drought susceptibility of a genotype is often measured as a function of the reduction in yield under drought stress (Blum, 1988)

Grain yield is a complex character made up of the interaction between different yield components and environmental effects. Because of these complex interactions, it is difficult to improve yield through breeding (especially in the early generation) if yield is the only factor recorded, suggesting that components characters should also be used as selection criteria for yield improvement. This is the reason why it is necessary to know the genetic architecture of yield components (Misra et al.,1994).

An understanding of genetic factors determining yield and yield components characters is a primary step for breeding studies. Generation mean analysis is a simple estimate but useful for estimating gene effects for a polygenic character. Its greatest merit laying in the ability to estimate epistatic gene effects such as additive $\times$ additive (i), dominance $\times$ dominance (j) and additive $\times$ dominance (I) effects (Mather and Jinks 1982).

This research was carried out to provide information about gene effects and available genetic variability for the most important quantitative characters of bread wheat, and to evaluate the variation and pattern of the transgressive segregation developed from backcrossing program for some yield and yield components characters under normal and water stress conditions. The effectiveness of backcross breeding programs can be improved by evaluating transgressive segregations for shelf life, and subsequently, selecting for those with high yield and other related characters before crossing them back to the recurrent parents.

\section{MATERIALS AND METHODS}

The materials used in this investigation as parents included four bread wheat genotypes (Triticum aestivum L. emend. Thell.), representing a wide range of diversity for several agronomic characters. The name and pedigree of these parental genotypes are presented in Table (1).

Table (1): Name and pedigree of four parental genotypes:

\begin{tabular}{|l|l|lc|}
\hline No & Genotype & \multicolumn{2}{|c|}{ Pedigree } \\
\hline 1 & Line \# 1 & \multicolumn{3}{|l|}{ Giza158/5/CFN/CNO"S"//RON/3/BB/NOR67/4/TL/3/ FN/TH//NAR59*2 } \\
\hline 2 & Sakha 93 & Sakha 92/TR 810328 & S.10232-3S-2S-4S-0S \\
\hline 3 & Sakha 94 & $\begin{array}{l}\text { Opata / Rayon // Kauz } \\
\text { 010Y-10M-015Y-0Y-0AP-0S. }\end{array}$ & CMBW90Y3180-0TOPM-3Y-010M-010M- \\
\hline 4 & Gemmiza 9 & Ald"S"/Huac//Cmh74A.630/Sx & CGM4583-5GM-1GM-0GM \\
\hline
\end{tabular}

In 2006/2007 season four different crosses were performed between the four wheat genotypes. The established crosses were selected as follows: Cross $1=($ Line $1 \times$ Sakha93 $)$, Cross $2=($ Line $1 \times$ Sakha94 $)$, Cross $3=$ (Sakha93 $\times$ Gemmiza 9) and Cross $4=($ Sakha $94 \times$ Gemmiza 9). 
In 2007/2008 season, the $F_{1}$ of each of the crosses were crossed back to its parents to produce $\mathrm{BC}_{1}\left(\mathrm{~F}_{1} \times \mathrm{P}_{1}\right)$ and $\mathrm{BC}_{2}\left(\mathrm{~F}_{1} \times \mathrm{P}_{2}\right)$. The $\mathrm{F}_{1}$ plants were selfed to produce $F_{2}$ seeds. In 2008/2009 season, the six population $\left(P_{1}, P_{2}\right.$, $F_{1}, F_{2}, B_{1}$ and $B_{2}$ ) were evaluated in two separate irrigation regime experiments. The first experiment (normal treatment) was irrigated three times after planting irrigation i.e. four irrigations were given through the whole season. The second experiment (drought treatment) was given only one surface-irrigation 33 days after the sowing date i.e. two irrigations were given through the whole season as shown in Table (2).

Table (2): Amount of supplied water and total rainfall in $\mathrm{m}^{3} / \mathrm{fed}$. at different treatments in 2008/2009 season.

\begin{tabular}{|l|c|c|c|c|c|c|c|}
\hline Irrigation & Sowing (1) & $\mathbf{2}$ & $\mathbf{3}$ & $\mathbf{4}$ & $\begin{array}{c}\text { Total } \\
\text { irrigation }\end{array}$ & Rainfall $^{*}$ & $\begin{array}{c}\text { Total water } \\
\mathbf{m}^{\mathbf{3}} / \mathbf{f e d}^{\text {f }}\end{array}$ \\
\hline Normal & 500 & 200 & 200 & 300 & 1200 & 142.8 & 1342.8 \\
\hline Stress & 500 & 200 & & & 700 & 142.8 & 842.8 \\
\hline
\end{tabular}

* Sakha Agric. Res. St., Kafr El-Sheikh.

The two experiments were designed in a randomized complete block design with three replications in the Experimental Farm at Sakha Agric. Res. St., Kafer El-Sheikh Governorate.

Each replicate consisted of 21 rows; $P_{1}, P_{2}$ and $F_{1}$ were planted in one row for each, $\mathrm{F}_{2}$ in 10 rows, $\mathrm{BC}_{1}$ and $\mathrm{BC}_{2}$ in 3 rows for each as well as two border rows. Rows were $4 \mathrm{~m}$ long and $30 \mathrm{~cm}$ apart with $20 \mathrm{~cm}$ between plants. Twenty grains were manually drilled in the rows on, 6 December 2008, Each experiment was surrounded by a wide border $(10 \mathrm{~m})$ to minimize the effects of water permeability. All other cultural practices, except irrigation, were applied as recommended for wheat cultivation. The two outside plants from each row and the two outer rows of each replicate (border) were excluded to avoid the border effect.

Studied characters: Data of the following characters were recorded from 10 plants of each $P_{1}, P_{2}$, and $F_{1}, 110$ Plants of $F_{2}$ and 40 plants of $B C_{1}$ and $B C_{2}$ for each replicate for the two experiments as following: Plant height $(\mathrm{cm})$, spikes number plant ${ }^{-1}$, grains number spike ${ }^{-1}, 100$-grain weight $(\mathrm{g})$, grain yield plant $^{-1}(\mathrm{~g})$, tolerance index, $\mathrm{TOL}=(\mathrm{Yp}-\mathrm{Ys})$, according to Rosielle and Hambling (1981) and yield reduction ratio, $Y r=1-(Y s / Y p)$, according to Golestani and Assad (1998). Where, (Ys) = grain yield under water stress and $(Y p)=$ grain yield under normal treatment.

The collected data were analyzed to test the differences among crosses under normal and water stress treatments and differences among parental genotypes for each cross using " $T$ " test before considering the biometrical analysis. Moreover, "F" ratio was calculated to test the significance of genetic variance among $F_{2}$ plants according to Allard (1999).

Scaling test and gene action parameters: Simple scaling tests (A, B and C) were applied according to Mather and Jinks (1982) to test the presence of nonallelic interactions. According to Jinks and Jones (1958), the following notation for gene effects have been used: additive (d), dominance $(\mathrm{h})$, additive $\times$ additive (i), additive $\times$ dominance $(\mathrm{j})$, dominance $\times$ dominance 
(I) effect. The type of epistasis was determined only when dominance (h) and dominance $\times$ dominance (I) effects were significant.

Genetic parameters: The genetic components of variances; mean degree of dominance $(H / D)^{1 / 2}$, heritability in broad sense $\left(h^{2}\right.$ b.s $)$ and narrow sense $\left(h^{2}{ }_{n . s}\right)$, heterosis above mid and better parents were calculated according to Mather and Jinks (1982) and genetic advance as percentage of the $F_{2}$ mean were estimated as reported by Allard (1999).

\section{RESULTS AND DISCUSSION}

\section{Generation means:}

The mean values of the yield and yield components characters of the four crosses under normal and water stress treatments are presented in Table (3). The results indicated that the means of the four crosses significantly decreased under the water stress treatment for all characters in most cases as the effect of water stress, except for grains number spike ${ }^{-1}$ of cross 4 and grain yield plant ${ }^{-1}$ of cross 1 which decreased without significant difference. On the other hand, 100-grain weight of cross 1 and cross 3 had significantly increased due to the effect of water stress. These results were in general agreement with Farhat (2005), El-Hawary (2006) and ShehabEldeen (2008).

Table (3): T-test for the differences between crosses under normal and water stress treatments for yield and yield components characters of four wheat crosses.

\begin{tabular}{|c|c|c|c|c|c|c|c|c|c|c|c|c|c|c|c|}
\hline \multirow{2}{*}{ \&̊ } & \multicolumn{3}{|c|}{$\begin{array}{c}\text { Plant height, } \\
\text { cm }\end{array}$} & \multicolumn{3}{|c|}{ 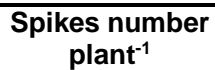 } & \multicolumn{3}{|c|}{$\begin{array}{c}\text { Grains number } \\
\text { spike }^{-1}\end{array}$} & \multicolumn{3}{|c|}{$\begin{array}{l}\text { 100-grain } \\
\text { weight, g }\end{array}$} & \multicolumn{3}{|c|}{$\begin{array}{l}\text { Grain yield } \\
\text { plant }^{-1}, \mathbf{g}\end{array}$} \\
\hline & $\mathbf{N}$ & S & $\begin{array}{c}\mathrm{T}- \\
\text { test }\end{array}$ & $\mathbf{N}$ & S & $\begin{array}{c}\mathrm{T}- \\
\text { test }\end{array}$ & $\mathbf{N}$ & S & $\begin{array}{c}\mathrm{T}- \\
\text { test }\end{array}$ & $\mathbf{N}$ & $\mathbf{S}$ & $\begin{array}{c}\mathrm{T}- \\
\text { test }\end{array}$ & $\mathbf{N}$ & S & $\begin{array}{c}\text { T- } \\
\text { test }\end{array}$ \\
\hline $\begin{array}{l}1 \\
2 \\
3 \\
4\end{array}$ & $\begin{array}{l}105.4 \\
114.6 \\
105.5 \\
112.7\end{array}$ & $\begin{array}{l}02.9 \\
12.4 \\
96.8 \\
07.6\end{array}$ & $\begin{array}{l}* * \\
\star * \\
\star * \\
\star *\end{array}$ & \begin{tabular}{|l|}
23.2 \\
24.8 \\
23.3 \\
26.3
\end{tabular} & $\begin{array}{l}20.8 \\
21.5 \\
20.1 \\
22.2\end{array}$ & $\begin{array}{l}* * \\
* * \\
* * \\
* *\end{array}$ & $\begin{array}{l}57.9 \\
66.4 \\
64.3 \\
60.4\end{array}$ & $\begin{array}{l}55.4 \\
62.6 \\
61.6 \\
59.3\end{array}$ & $\begin{array}{c}\star \star \\
\star \star \\
\star \star \\
\text { N.S }\end{array}$ & $\begin{array}{l}4.3 \\
4.8 \\
4.3 \\
4.6\end{array}$ & $\begin{array}{l}4.5 \\
4.7 \\
4.7 \\
4.4\end{array}$ & $\begin{array}{l}* \star \\
\star \\
\star * \\
\star *\end{array}$ & $\begin{array}{l}47.5 \\
55.6 \\
45.8 \\
54.7\end{array}$ & $\begin{array}{l}47.5 \\
51.1 \\
42.5 \\
44.7\end{array}$ & $\begin{array}{l}\text { N.S } \\
* * \\
* * \\
* *\end{array}$ \\
\hline Mean & 109.6 & 104.9 & ** & 24.4 & 21.2 & ** & 62.3 & 59.7 & $\star *$ & 4.5 & 4.6 & ** & 50.9 & 46.4 & $\star \star$ \\
\hline
\end{tabular}

${ }^{*},{ }^{* *}=$ significant at 0.05 and 0.01 levels of probability, respectively.

$\begin{array}{ll}\mathrm{N}=\text { Normal treatment } & \mathrm{S}=\text { water stress treatment }\end{array}$

Cross 1= Line $1 \times$ Sakha $93 \quad$ Cross $2=$ Line $1 \times$ Sakha 94

Cross 3 = Sakha $93 \times$ Gemmiza $9 \quad$ Cross 4 = Sakha $94 \times$ Gemmiza 9

The T-test of differences between parents of each cross under each treatment, as shown in Table (4) were highly significant in most cases in the four studied crosses under both water treatments. Therefore, a considerable amount of genetic variations existed among the parents used in this study. The data in Tables (5 and 6 ) indicated that $F_{1}$ generation values were between the two parents for most cases in the four crosses under both treatments. These results indicated the presence of partial dominance of genes controlling these characters. The data showed that both $\mathrm{BC}_{1}$ and $\mathrm{BC}_{2}$ mean values tended toward the mean of the recurrent parent for all characters in the four crosses under both water treatments. The segregating populations $\left(F_{2}, B_{1}\right.$ and $\left.B_{2}\right)$ means indicated that segregation took the 
direction toward the shortest parent, lowest parent at spikes number plant ${ }^{-1}$, grains number spike ${ }^{-1}$, grain yield plant $^{-1}$ and heavies 100-grain weight at most cases in all crosses under both water treatments. The results indicated that Sakha 94 and Line 1 were the highest parents in grain yield plant ${ }^{-1}$ under both water treatments and cross 2 was the highest in most generations at most cases under both water treatments.

Table (4): T-test for the differences between the four parents of spring wheat involved in the four crosses for yield and yield components characters under normal and water stress treatments.

\begin{tabular}{|c|c|c|c|c|c|c|}
\hline \multirow{2}{*}{ Character } & \multirow{2}{*}{ Treat } & Cross 1 & Cross 2 & Cross 3 & \multicolumn{2}{|c|}{ Cross 4} \\
\hline & & \begin{tabular}{l|l}
$P_{1}$ & $P_{2}$ \\
\end{tabular} & \begin{tabular}{l|l}
$P_{1}$ & $P_{3}$ \\
\end{tabular} & \begin{tabular}{l|l}
$\mathbf{P}_{2}$ & $\mathbf{P}_{4}$ \\
\end{tabular} & $\mathbf{P}_{3}$ & $\mathbf{P}_{4}$ \\
\hline \multirow{2}{*}{ Plant height, $\mathrm{cm}$} & $\mathrm{N}$ & ** & ** & $\star *$ & \multicolumn{2}{|c|}{ * } \\
\hline & $\mathrm{S}$ & ** & ** & ** & \multicolumn{2}{|c|}{ ** } \\
\hline \multirow{2}{*}{ Spikes number plant ${ }^{-1}$} & $\mathrm{~N}$ & ** & ** & ** & \multicolumn{2}{|c|}{ ** } \\
\hline & $\mathrm{S}$ & N.S & ** & ** & \multicolumn{2}{|c|}{ ** } \\
\hline \multirow{2}{*}{ Grains number spike ${ }^{-1}$} & $\mathrm{~N}$ & ** & N.S & ** & \multicolumn{2}{|c|}{ * } \\
\hline & $\mathrm{S}$ & ** & ** & ** & \multicolumn{2}{|c|}{ ** } \\
\hline \multirow{2}{*}{ 100-grain weight, g } & $\mathrm{N}$ & ** & ** & ** & \multicolumn{2}{|c|}{ ** } \\
\hline & $\mathrm{S}$ & ** & ** & ** & \multicolumn{2}{|c|}{ * } \\
\hline \multirow{2}{*}{ Grain yield plant ${ }^{-1}, \mathrm{~g}$} & $\mathrm{~N}$ & ** & ** & ** & \multicolumn{2}{|c|}{ ** } \\
\hline & $\mathrm{S}$ & ** & N.S & ** & & \\
\hline
\end{tabular}

The results in Table 7 indicate that Line 1 and Sakha 93 were the lowest sensitive to water stress so that cross 1 was low sensitive to water stress at most of generations which had low values of both TOL and YR. Therefore, cross 1 was favored for water stress treatment.

Scaling test and generation mean analysis:

Scaling test data of the studied characters in the four wheat crosses under normal and water stress treatments are presented in Tables (8 and 9). The calculated values of $A, B$ and $C$ scaling tests for all studied characters in the four crosses under both water treatments were significant, except for plant height of cross 3 and cross 4 and 100-grain weight of cross 2 under water stress treatment. These findings indicated that the six parameter model is valid to explain the nature of gene action for these characters. Meanwhile, non of $A, B$ or $C$ scaling tests were significant, indicating the adequacy of the three parameter model to explain the type of gene action. These results are in general agreement with those of Tammam (2005), El-Hag (2006), Abd ElRahaman, Magda and Hammad (2009), Aboshosha and Hammad (2009),

Type of gene action 
Sultan, M. S. et al.

Table (5): Means $(\bar{X})$ and variances $\left(S^{2}\right)$ of $P_{1}, P_{2}, M . P, F_{1}, F_{2}, B C_{1}$ and $\mathrm{BC}_{2}$ populations of plant height and spikes number plant ${ }^{-1}$ characters for four crosses of spring wheat under normal and water stress treatments.

\begin{tabular}{|c|c|c|c|c|c|c|c|c|c|c|}
\hline Character & Cross & Treat. & Statis & $\mathbf{P}_{1}$ & $\mathbf{P}_{2}$ & M.P & $F_{1}$ & $F_{2}$ & $\mathrm{BC}_{1}$ & $\mathrm{BC}_{2}$ \\
\hline \multirow{16}{*}{ 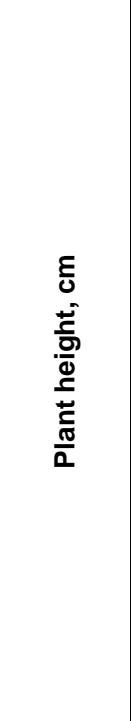 } & \multirow{4}{*}{1} & \multirow[t]{2}{*}{$\mathrm{N}$} & $\bar{x}$ & 118.50 & 93.67 & \multirow[t]{2}{*}{106.08} & 111.67 & 103.09 & 114.71 & 100.75 \\
\hline & & & $S^{2}$ & 14.05 & & & 5.75 & 231.30 & 149.28 & 176.74 \\
\hline & & \multirow[t]{2}{*}{$S$} & $\bar{x}$ & 116.33 & 90.67 & \multirow[t]{2}{*}{103.50} & 106.50 & 101.92 & 109.42 & 98.25 \\
\hline & & & $S^{2}$ & 11.95 & 8.16 & & 7.16 & 325.69 & 186.63 & 168.34 \\
\hline & \multirow{4}{*}{2} & \multirow[t]{2}{*}{$\mathrm{N}$} & $\bar{x}$ & 118.50 & 114.83 & \multirow[t]{2}{*}{116.67} & 117.83 & 114.92 & 113.67 & 112.58 \\
\hline & & & $S^{2}$ & 14.05 & 16.35 & & 6.35 & 144.90 & 100.31 & 114.28 \\
\hline & & \multirow[t]{2}{*}{$S$} & $\bar{x}$ & 116.33 & 110.33 & \multirow[t]{2}{*}{113.33} & 115.67 & 112.11 & 111.04 & 113.38 \\
\hline & & & $\mathrm{S}^{2}$ & 11.95 & 20.57 & & 6.44 & 139.09 & 122.23 & 104.27 \\
\hline & \multirow{4}{*}{3} & \multirow[t]{2}{*}{$\mathrm{N}$} & $\bar{x}$ & 93.67 & 116.83 & \multirow[t]{2}{*}{105.25} & 108.67 & 105.70 & 102.08 & 107.58 \\
\hline & & & $S^{2}$ & 5.06 & 6.01 & & 6.78 & 368.81 & 152.77 & 201.25 \\
\hline & & \multirow[t]{2}{*}{ S } & $\bar{x}$ & 90.67 & 103.67 & \multirow[t]{2}{*}{97.17} & 98.33 & 95.84 & 95.63 & 100.25 \\
\hline & & & $\mathrm{S}^{2}$ & 8.16 & 18.85 & & 9.20 & 312.21 & 211.16 & 187.75 \\
\hline & \multirow{4}{*}{4} & \multirow[t]{2}{*}{$\mathrm{N}$} & $\bar{x}$ & 114.83 & 116.83 & \multirow[t]{2}{*}{115.83} & 117.24 & 113.14 & 110.04 & 111.63 \\
\hline & & & $S^{2}$ & 16.35 & 6.01 & & 9.98 & 111.33 & 96.43 & 69.82 \\
\hline & & \multirow[t]{2}{*}{$S$} & $\bar{x}$ & 110.33 & 103.00 & \multirow[t]{2}{*}{106.67} & 109.67 & 107.83 & 108.92 & 105.17 \\
\hline & & & $S^{2}$ & 20.57 & 42.41 & & 22.30 & 104.18 & 56.80 & 52.91 \\
\hline \multirow{16}{*}{ 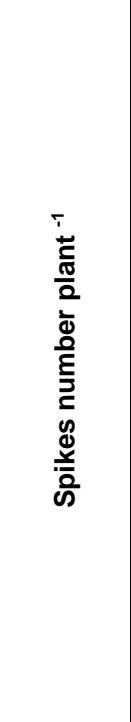 } & \multirow{4}{*}{1} & \multirow[t]{2}{*}{$\mathrm{N}$} & $\bar{x}$ & 24.87 & 34.10 & \multirow[t]{2}{*}{29.48} & 23.03 & 24.22 & 20.08 & 20.49 \\
\hline & & & $S^{2}$ & 16.46 & 38.23 & & 31.41 & 70.80 & 56.33 & 44.76 \\
\hline & & \multirow[t]{2}{*}{$S$} & $\bar{x}$ & 21.93 & 22.23 & \multirow[t]{2}{*}{22.08} & 16.47 & 23.10 & 16.68 & 19.28 \\
\hline & & & $S^{2}$ & 13.03 & 20.87 & & 9.98 & 86.55 & 29.39 & 48.17 \\
\hline & & $\mathrm{N}$ & $\bar{x}$ & 24.87 & 33.30 & 29.08 & 23.63 & 25.31 & 21.47 & 24.87 \\
\hline & 2 & & $\mathrm{~S}^{2}$ & 16.46 & 31.18 & & 26.03 & 95.16 & 70.39 & 70.42 \\
\hline & & $S$ & $\bar{x}$ & 21.93 & 27.03 & 24.48 & 20.47 & 21.72 & 19.74 & 21.58 \\
\hline & & & $\mathrm{S}^{2}$ & 13.03 & 33.57 & & 14.05 & 60.31 & 52.45 & 59.40 \\
\hline & & $\mathrm{N}$ & $\bar{x}$ & 34.10 & 24.73 & 29.42 & 23.23 & 23.33 & 22.79 & 20.53 \\
\hline & 3 & & $S^{2}$ & 38.23 & 36.75 & & 37.43 & 61.58 & 60.46 & 52.86 \\
\hline & & $S$ & $\bar{x}$ & 22.23 & 15.37 & 18.80 & 16.93 & 21.78 & 19.36 & 17.52 \\
\hline & & & $\mathrm{S}^{2}$ & 20.87 & 18.65 & & 12.82 & 50.82 & 31.51 & 31.33 \\
\hline & & $\mathrm{N}$ & $\bar{x}$ & 33.30 & 24.73 & 29.02 & 27.21 & 27.03 & 27.78 & 21.49 \\
\hline & 4 & & $S^{2}$ & 31.18 & 36.75 & & 30.10 & 116.01 & 73.70 & 72.99 \\
\hline & & $S$ & $\bar{x}$ & 27.13 & 15.37 & 21.25 & 18.97 & 23.15 & 22.24 & 20.92 \\
\hline & & & $S^{2}$ & 33.57 & 18.65 & & 25.96 & 76.17 & 47.73 & 51.77 \\
\hline
\end{tabular}

Cross 1= Line $1 \times$ Sakha $93 \quad$ Cross 2 = Line $1 \times$ Sakha 94

Cross 3 = Sakha $93 \times$ Gemmiza $9 \quad$ Cross $4=$ Sakha $94 \times$ Gemmiza 9

$\mathrm{N}=$ Normal treatment

$\mathrm{S}=$ water stress treatment 
Table (6): Means $(\bar{X})$ and variances $\left(S^{2}\right)$ of $P_{1}, P_{2}, M . P, F_{1}, F_{2}, B C_{1}$ and $\mathrm{BC}_{2}$ populations of grains number spike ${ }^{-1}, 100$-grain weight and grain yield plant ${ }^{-1}$ characters for four crosses of spring wheat under normal and water stress treatments.

\begin{tabular}{|c|c|c|c|c|c|c|c|c|c|c|}
\hline Character & Cross & Treat. & Statis. & $P_{1}$ & $\mathbf{P}_{2}$ & M.P & $\overline{F_{1}}$ & $\overline{F_{2}}$ & $\mathrm{BC}_{1}$ & $\mathrm{BC}_{2}$ \\
\hline \multirow{13}{*}{ 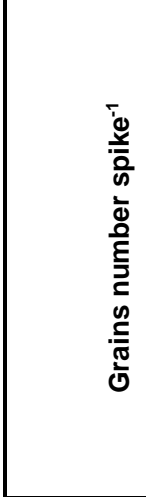 } & \multirow[b]{2}{*}{1} & $\mathrm{~N}$ & $\begin{array}{l}\bar{x} \\
S^{2}\end{array}$ & $\begin{array}{l}70.87 \\
99.36\end{array}$ & $\begin{array}{l}61.37 \\
75.62\end{array}$ & 66.12 & $\begin{array}{l}62.37 \\
98.17\end{array}$ & $\begin{array}{c}57.67 \\
281.76\end{array}$ & $\begin{array}{c}52.54 \\
231.39\end{array}$ & \begin{tabular}{|c|}
58.94 \\
266.37
\end{tabular} \\
\hline & & $\mathrm{S}$ & & $\begin{array}{l}66.27 \\
88.00\end{array}$ & $\begin{array}{l}54.33 \\
88.85\end{array}$ & 60.30 & $\begin{array}{l}64.43 \\
99.15\end{array}$ & $\begin{array}{c}55.41 \\
292.94\end{array}$ & $\begin{array}{c}57.25 \\
230.27\end{array}$ & $\begin{array}{c}48.78 \\
269.60\end{array}$ \\
\hline & \multirow{3}{*}{2} & $\bar{N}$ & & 70.87 & 67.43 & 69.15 & 70.83 & \begin{tabular}{|l|}
69.19 \\
\end{tabular} & \begin{tabular}{|l|}
58.53 \\
\end{tabular} & \begin{tabular}{|l|}
64.24 \\
\end{tabular} \\
\hline & & & $\mathbf{S}^{2}$ & 99.36 & 70.39 & & 86.35 & 261.34 & 251.18 & 258.84 \\
\hline & & $S$ & $\mathbf{S}^{2}$ & $\begin{array}{l}66.27 \\
88.00\end{array}$ & $\begin{array}{c}75.33 \\
105.20\end{array}$ & 70.80 & $\begin{array}{l}65.00 \\
97.93\end{array}$ & $\begin{array}{c}63.77 \\
240.32\end{array}$ & $\begin{array}{c}59.38 \\
233.26\end{array}$ & \begin{tabular}{|c}
57.71 \\
232.48
\end{tabular} \\
\hline & \multirow{4}{*}{3} & $\mathrm{~N}$ & & 61.37 & 72.20 & 66.78 & 64.67 & 65.36 & 60.94 & \begin{tabular}{|l|}
63.39 \\
\end{tabular} \\
\hline & & & $\mathbf{S}^{2}$ & 75.62 & 90.99 & & 88.23 & 380.37 & 226.44 & 200.39 \\
\hline & & S & 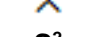 & 54.33 & 68.07 & 61.20 & 63.13 & 63.40 & 57.76 & 60.01 \\
\hline & & & $\mathbf{S}^{2}$ & 88.85 & 118.62 & & 103.15 & 304.06 & 280.54 & 276.80 \\
\hline & \multirow{4}{*}{4} & $\bar{N}$ & & 67.43 & 72.20 & 69.82 & 69.17 & \begin{tabular}{|l|}
54.79 \\
\end{tabular} & \begin{tabular}{|l|}
67.88 \\
\end{tabular} & 61.60 \\
\hline & & & $\mathbf{S}^{2}$ & 70.39 & 90.99 & & 85.08 & 415.66 & 215.73 & 329.25 \\
\hline & & $S$ & $\pi$ & 75.33 & 68.07 & 71.70 & 51.23 & \begin{tabular}{|l|}
57.73 \\
\end{tabular} & \begin{tabular}{|l|}
60.56 \\
\end{tabular} & 57.90 \\
\hline & & & $\mathbf{S}^{2}$ & 105.20 & 118.62 & & 100.81 & 414.99 & 211.71 & 327.84 \\
\hline \multirow{16}{*}{ 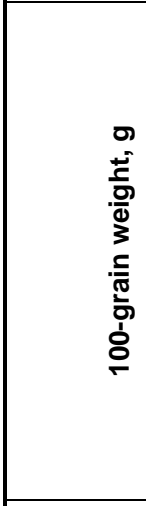 } & \multirow{4}{*}{1} & $\mathrm{~N}$ & & 5.10 & 4.18 & 4.64 & 4.30 & 4.23 & 4.20 & 4.53 \\
\hline & & & $\mathbf{S}^{2}$ & 0.33 & 0.24 & & 0.33 & 0.99 & 0.75 & 0.76 \\
\hline & & S & & 4.96 & 3.87 & 4.42 & 5.28 & 4.31 & 4.99 & 4.46 \\
\hline & & & $\mathbf{s}^{2}$ & 0.19 & 0.41 & & 1.07 & 1.25 & 1.22 & 1.21 \\
\hline & \multirow{4}{*}{2} & $\bar{N}$ & & 5.10 & 4.25 & 4.67 & 4.98 & 4.67 & 5.11 & 4.80 \\
\hline & & & $\mathbf{S}^{2}$ & 0.33 & 0.14 & & 0.11 & 0.42 & 0.39 & 0.35 \\
\hline & & $S$ & & 4.96 & 4.14 & 4.55 & 4.86 & 4.69 & 4.93 & 4.56 \\
\hline & & & $\mathbf{S}^{2}$ & 0.19 & 0.10 & & 0.22 & 0.79 & 0.66 & 0.70 \\
\hline & \multirow{4}{*}{3} & $\mathrm{~N}$ & & 4.18 & 4.80 & 4.49 & 4.79 & 4.51 & 3.86 & 3.95 \\
\hline & & & $\mathbf{S}^{2}$ & 0.24 & 0.16 & & 0.57 & 1.33 & 0.63 & 0.73 \\
\hline & & S & & 3.87 & 4.36 & 4.11 & 4.60 & 4.84 & 4.34 & 4.80 \\
\hline & & & $\mathbf{S}^{2}$ & 0.41 & 0.18 & & 0.30 & 0.77 & 0.71 & 0.61 \\
\hline & \multirow{4}{*}{4} & $\mathrm{~N}$ & & 4.25 & 4.80 & 4.52 & 5.15 & 4.42 & 4.69 & 4.87 \\
\hline & & & $\$^{2}$ & 0.14 & 0.16 & & 0.07 & 1.42 & 0.28 & 0.76 \\
\hline & & S & & 4.14 & 4.36 & 4.25 & 4.84 & 4.41 & 4.51 & 4.29 \\
\hline & & & $\mathbf{S}^{2}$ & 0.10 & 0.18 & & 0.29 & 0.67 & 0.38 & 0.62 \\
\hline \multirow{15}{*}{ 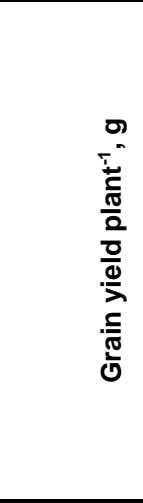 } & \multirow{4}{*}{1} & $\mathrm{~N}$ & & 70.92 & 43.22 & 57.07 & 47.46 & 49.24 & 43.81 & 41.79 \\
\hline & & & $\mathbf{S}^{2}$ & 69.13 & 20.62 & & 78.29 & 562.88 & 284.19 & 330.19 \\
\hline & & $\mathrm{S}$ & & 65.39 & 41.79 & 53.59 & 47.31 & 51.56 & \begin{tabular}{|l|}
43.53 \\
\end{tabular} & \begin{tabular}{|l|}
37.33 \\
\end{tabular} \\
\hline & & & $\mathbf{S}^{2}$ & 91.25 & 77.06 & & 82.12 & 595.99 & 196.18 & 300.74 \\
\hline & \multirow{4}{*}{2} & $\mathrm{~N}$ & & 70.92 & 78.70 & 74.81 & 57.21 & 52.22 & 53.29 & 56.94 \\
\hline & & & $\mathbf{s}^{2}$ & 69.13 & 93.51 & & 81.38 & 614.16 & 550.46 & 516.71 \\
\hline & & S & $\mathbf{S}^{2}$ & $\begin{array}{l}65.39 \\
9125\end{array}$ & $\begin{array}{l}61.55 \\
93.99\end{array}$ & 63.47 & $\begin{array}{c}51.07 \\
10017\end{array}$ & $\begin{array}{c}54.06 \\
42357\end{array}$ & $\begin{array}{c}45.72 \\
385.37\end{array}$ & $\begin{array}{c}42.23 \\
31255\end{array}$ \\
\hline & & $\mathrm{N}$ & $3=$ & $\frac{91.25}{43.22}$ & $\frac{93.99}{57.91}$ & 50.5 & $\frac{100.17}{55.88}$ & $\frac{423.57}{46.17}$ & \begin{tabular}{|c|}
385.37 \\
41.55
\end{tabular} & \begin{tabular}{|l}
312.55 \\
1425
\end{tabular} \\
\hline & \multirow{3}{*}{3} & & $S^{2}$ & 20.62 & 62.84 & & 86.49 & 530.72 & 334.29 & 318.96 \\
\hline & & $\mathrm{S}$ & & 41.79 & 29.07 & 35.43 & 49.96 & 45.32 & 45.17 & 33.71 \\
\hline & & & $\mathbf{S}^{2}$ & 77.06 & 64.29 & & 99.85 & 418.11 & 338.09 & 226.36 \\
\hline & \multirow{4}{*}{4} & $\mathrm{~N}$ & & 78.70 & 57.91 & \begin{tabular}{|c|}
68.31 \\
\end{tabular} & 48.63 & \begin{tabular}{|l|}
58.57 \\
\end{tabular} & \begin{tabular}{|l|}
50.47 \\
\end{tabular} & 43.14 \\
\hline & & & $\mathbf{S}^{2}$ & 93.51 & 62.84 & & 86.19 & 902.31 & 390.44 & 305.16 \\
\hline & & S & & 61.55 & 29.07 & 45.31 & 38.98 & 46.96 & \begin{tabular}{|l|}
43.72 \\
\end{tabular} & 40.43 \\
\hline & & & $\mathbf{S}^{2}$ & 93.99 & 64.29 & & 119.20 & 604.30 & 256.89 & 310.82 \\
\hline C & & & & & & & & & & \\
\hline
\end{tabular}


Sultan, M. S. et al.

Table 7: Tolerance index (TOL) and yield reduction ratio of yield (YR) for grain yield plant ${ }^{-1}$ at all generations of the four crosses.

\begin{tabular}{|l|c|c|c|c|c|}
\hline Generations & $\begin{array}{c}\text { Stress } \\
\text { indicators }\end{array}$ & Cross 1 & Cross 2 & Cross 3 & Cross 4 \\
\hline $\mathrm{P}_{1}$ & TOL & 5.52 & 5.52 & 1.43 & 17.15 \\
& YR & 0.077 & 0.077 & 0.033 & 0.217 \\
\hline $\mathrm{P}_{2}$ & TOL & 1.43 & 17.15 & 28.84 & 28.84 \\
& YR & 0.033 & 0.217 & 0.498 & 0.498 \\
\hline $\mathrm{F}_{1}$ & TOL & 0.16 & 6.14 & 5.93 & 9.66 \\
& YR & 0.003 & 0.107 & 0.106 & 0.198 \\
\hline \multirow{2}{*}{$\mathrm{F}_{2}$} & TOL & -2.32 & -1.84 & 0.85 & 11.61 \\
& YR & -0.047 & -0.0352 & 0.018 & 0.198 \\
\hline $\mathrm{BC}_{1}$ & TOL & 0.28 & 7.57 & -3.62 & 6.75 \\
& YR & 0.006 & 0.142 & -0.087 & 0.134 \\
\hline $\mathrm{BC}_{2}$ & TOL & 4.46 & 14.72 & 10.54 & 2.71 \\
& YR & 0.106 & 0.258 & 0.238 & 0.063 \\
\hline
\end{tabular}

Cross 1= Line $1 \times$ Sakha 93

Cross 2 = Line $1 \times$ Sakha 94

Cross 3 = Sakha $93 \times$ Gemmiza $9 \quad$ Cross 4 = Sakha $94 \times$ Gemmiza 9

The results in Tables $(8$ and 9$)$ indicated that the mean effect $(m)$ was significant for all studied characters in the four crosses under both water treatments. Additive gene effects (d) were highly significant at most cases for all yield and yield components characters at the four crosses under both water treatments. Dominance gene effects (h) were significant or highly significant for plant height in cross 1, cross 2 under normal treatment and cross 4 under both water treatments; for spikes number plant $^{-1}$, grains number spike ${ }^{-1}$ and grain yield plant ${ }^{-1}$ in most cases under both water treatments; for 100-grain weight at cross 1 under water stress treatment, cross 2 under both water treatments, cross 3 and cross 4 under normal treatment. Additive $\times$ additive gene effects (i) were significant for plant height in cross 1 and cross 4 under normal treatment; for grains number spike ${ }^{-1}$ in cross 2, cross 3 under both water treatments and cross 4 under normal treatment; for spikes number plant ${ }^{-1}, 100$-grain weight and grain yield plant $^{-1}$ in most cases under both water treatments.

Additive $\times$ dominance gene effects (j) were significant or highly significant for plant height in cross 2 and cross 3 under water stress and normal treatments, respectively. For spikes number plant ${ }^{-1}$ in cross 1 under both water treatments and cross 4 under water stress treatment, for grains number spike ${ }^{-1}$ at cross 1 and cross 4 under normal treatment and cross 2 under both water treatments; for 100-grain weight in cross 1 and cross 4 under normal and water stress treatments, respectively. For grain yield plant ${ }^{-1}$ in cross 1 under both water treatments, cross 3 and cross 4 under water stress treatment.

Dominance $\times$ dominance gene effects (I) were significant or highly significant for plant height in cross 2 and cross 4 under normal treatment; for spikes number plant ${ }^{-1}$, grains number spike ${ }^{-1}$ and grain yield plant ${ }^{-1}$ in most cases under both water treatments; for 100-grain weight in cross 2, cross 3 and cross 4 under normal treatment. 
J. Plant Production, Mansoura Univ., Vol. 2 (2), February, 2011 8 
Sultan, M. S. et al.

9 
Among the epistasis components, the dominance $\times$ dominance was greater in magnitudes than additive $\times$ additive and Additive $\times$ dominance at most cases in plant height, spikes number plant ${ }^{-1}$, grains number spike ${ }^{-1}$ and grain yield plant ${ }^{-1}$ under both water treatments.

These results indicated that additive effects were important in inheritance of plant height at most cases in the four studied crosses under both water treatments. However, additive, dominance and epistasis were important for inheritance of spikes number plant ${ }^{-1}$, grains number spike ${ }^{-1}$, 100 -grain weight and grain yield plant ${ }^{-1}$ in the four crosses under both water treatments. These results are in close agreement with those obtained by Tahmasebi et al., (2007), ShehabEldeen (2008) and Abd El-Rahman, Magda and Hammad (2009).

Components of genetic variance:

The results in Table (10) indicated that additive variance played the greatest and the important role in the inheritance for plant height, spikes number plant ${ }^{-1}$ and grain yield plant $^{-1}$ at most cases under both water treatments. Also, Partial dominance was found at most cases which can be calculated under both water treatments for these characters. Indicating that, selection for these characters might be more effective in early generations for improving such characters in the four studied crosses, however, it would be better if it was delayed to later generations. On the other hand, dominance genetic variance was the greatest and the important in the inheritance for grains number spike ${ }^{-1}$ and 100 -grain weight at most cases under both water treatments. Also, over dominance was found at most cases which can be calculated under both water treatments for these characters. Indicating that, selection for these characters might be more effective in later generations for improving such characters in the four studied crosses. When dominance variance component was negative as estimate to zero, the average degree of dominance was not calculated as shown at some cases. These results were in general agreement with those obtained by Tammam (2005), El-Hawary (2006), Tahmasebi et al.(2007), Ahmadi and Bajelan (2008) and Abd ElRahman, Magda and Hammad (2009).

Heterosis, heritability and expected genetic advance:

The positive heterosis was the desirable for all yield and yield components characters. The results in Table (11) indicated that the positive significant heterosis over the mid-parents for plant height at cross 1 under both water treatments, cross 2 and cross 4 under water stress, and cross 3 under normal treatment; For grains number spike ${ }^{-1}$ at cross 1 under water stress treatment; For 100-grain weight at the four crosses under both water treatments, except cross 1 under normal treatment; For grain yield plant ${ }^{-1}$ at cross 3 under both water treatments. Also the positive heterosis over the better parent was shown for 100-grain weight at cross 1 and cross 3 under water stress treatment and cross 4 under both water treatments; for grain yield plant ${ }^{-1}$ at cross 3 under water stress treatment.

Heritability in broad sense ( $\left.h_{b . s}\right)$ had medium to high percentages for all studied characters at the four crosses under both water treatments. These results are in agreement with those obtained by El-Hawary (2006) and Kandic et al., (2009). 
Sultan, M. S. et al.

Table (10): Estimates components of genetic variance and average degree of dominance for yield and yield components characters in four crosses of spring wheat under normal and water stress treatments.

\begin{tabular}{|c|c|c|c|c|c|c|c|}
\hline character & Cross & Treat. & $\sigma^{2} E$ & $\sigma^{2} g$ & $\sigma^{2} D$ & $\sigma^{2} H$ & $(H / D)^{1 / 2}$ \\
\hline \multirow{8}{*}{ 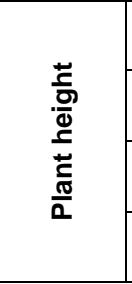 } & \multirow{2}{*}{1} & $\mathrm{~N}$ & 8.29 & 223.01 & 136.57 & 86.44 & 0.80 \\
\hline & & $\mathrm{S}$ & 9.09 & 316.60 & 296.41 & 20.19 & 0.26 \\
\hline & \multirow{2}{*}{2} & $\mathrm{~N}$ & 12.25 & 132.65 & 75.22 & 57.43 & 0.87 \\
\hline & & $\mathrm{S}$ & 12.99 & 126.10 & 51.69 & 74.41 & 1.20 \\
\hline & \multirow{2}{*}{3} & $\mathrm{~N}$ & 5.95 & 362.87 & 383.61 & -20.74 & $\square$ \\
\hline & & $S$ & 12.07 & 300.14 & 225.51 & 74.63 & 0.58 \\
\hline & \multirow{2}{*}{4} & $\mathrm{~N}$ & 10.78 & 100.56 & 56.42 & 44.13 & 0.88 \\
\hline & & $\mathrm{S}$ & 20.57 & 83.61 & 98.65 & -15.04 & $\square$ \\
\hline \multirow{8}{*}{ 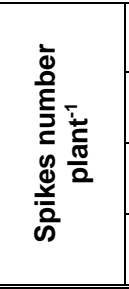 } & \multirow{2}{*}{1} & $\mathrm{~N}$ & 28.70 & 42.10 & 40.51 & 1.58 & 0.20 \\
\hline & & $S$ & 14.63 & 71.92 & 95.53 & -23.61 & $\square$ \\
\hline & \multirow{2}{*}{2} & $\mathrm{~N}$ & 24.56 & 70.60 & 49.51 & 21.09 & 0.65 \\
\hline & & $\mathrm{S}$ & 20.22 & 40.09 & 8.76 & 31.33 & 1.89 \\
\hline & \multirow{2}{*}{3} & $\mathrm{~N}$ & 37.47 & 24.11 & 9.85 & 14.26 & 1.20 \\
\hline & & $\mathrm{S}$ & 17.45 & 33.37 & 38.81 & -5.44 & $\square$ \\
\hline & \multirow{2}{*}{4} & $\mathrm{~N}$ & 32.68 & 83.33 & 85.33 & -2.00 & $\square$ \\
\hline & & $\mathrm{S}$ & 26.06 & 50.11 & 52.83 & -2.73 & $\square$ \\
\hline \multirow{8}{*}{ 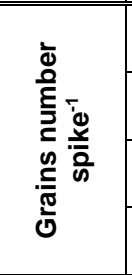 } & \multirow{2}{*}{1} & $\mathrm{~N}$ & 91.05 & 190.71 & 65.76 & 124.95 & 1.38 \\
\hline & & $\mathrm{S}$ & 92.00 & 200.94 & 86.00 & 114.94 & 1.16 \\
\hline & \multirow{2}{*}{2} & $\mathrm{~N}$ & 85.37 & 175.97 & 12.66 & 163.31 & 3.59 \\
\hline & & $\mathrm{S}$ & 97.04 & 143.28 & 14.90 & 128.38 & 2.94 \\
\hline & \multirow{2}{*}{3} & $\mathrm{~N}$ & 84.95 & 295.42 & 333.90 & -38.48 & $\square$ \\
\hline & & $\mathrm{S}$ & 103.54 & 200.52 & 50.78 & 149.74 & 1.72 \\
\hline & \multirow{2}{*}{4} & $\mathrm{~N}$ & 80.73 & 334.93 & 286.33 & 48.60 & 0.41 \\
\hline & & $\mathrm{S}$ & 108.21 & 306.79 & 290.44 & 16.35 & 0.24 \\
\hline \multirow{8}{*}{ 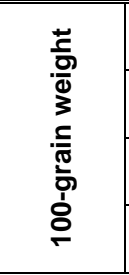 } & \multirow{2}{*}{1} & $\mathrm{~N}$ & 0.30 & 0.69 & 0.47 & 0.23 & 0.70 \\
\hline & & $\mathrm{S}$ & 0.56 & 0.69 & 0.07 & 0.62 & 2.96 \\
\hline & \multirow{2}{*}{2} & $\mathrm{~N}$ & 0.20 & 0.22 & 0.10 & 0.12 & 1.09 \\
\hline & & $S$ & 0.17 & 0.63 & 0.23 & 0.40 & 1.33 \\
\hline & \multirow{2}{*}{3} & $\mathrm{~N}$ & 0.33 & 1.00 & 1.29 & -0.29 & $\square$ \\
\hline & & $\mathrm{S}$ & 0.30 & 0.48 & 0.22 & 0.25 & 1.07 \\
\hline & \multirow{2}{*}{4} & $\mathrm{~N}$ & 0.12 & 1.29 & 1.80 & -0.51 & $\square$ \\
\hline & & $\mathrm{S}$ & 0.19 & 0.48 & 0.34 & 0.14 & 0.64 \\
\hline \multirow{8}{*}{ 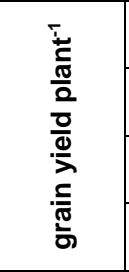 } & \multirow{2}{*}{1} & $\mathrm{~N}$ & 56.02 & 506.86 & 511.38 & -4.52 & $\square$ \\
\hline & & $\mathrm{S}$ & 83.48 & 512.52 & 695.07 & -182.55 & $\square$ \\
\hline & \multirow[b]{2}{*}{2} & $\mathrm{~N}$ & 81.34 & 532.81 & 161.14 & 371.68 & 1.52 \\
\hline & & $\mathrm{S}$ & 95.14 & 328.43 & 149.22 & 179.21 & 1.10 \\
\hline & \multirow{2}{*}{3} & $\mathrm{~N}$ & 56.65 & 474.07 & 408.19 & 65.88 & 0.40 \\
\hline & & $\mathrm{S}$ & 80.40 & 337.71 & 271.77 & 65.94 & 0.49 \\
\hline & \multirow{2}{*}{4} & $\mathrm{~N}$ & 80.72 & 821.59 & 1109.02 & -287.43 & $\square$ \\
\hline & & $\mathrm{S}$ & 92.49 & 511.81 & 640.90 & -129.09 & $\square$ \\
\hline
\end{tabular}

${ }^{*},{ }^{* *}=$ significant at 0.05 and 0.01 levels of probability, respectively.

$\mathrm{N}=$ Normal treatment

Cross 1= Line $1 \times$ Sakha 93

Sakha $93 \times$ Gemmiza 9

$\sigma^{2} \mathrm{ph}=$ Phenotypic variance

$\sigma^{2} \mathrm{~g}=$ Genotypic variance

$\sigma^{2} \mathrm{H}=$ Dominance variance
$\mathbf{S}=$ water stress treatment

Cross $2=$ Line $1 \times$ Sakha 94Cross $3=$

Cross $4=$ Sakha $94 \times$ Gemmiza 9

$\sigma^{2} \mathrm{E}=$ Environment variance

$\sigma^{2} D=$ Additive variance

$(H / D)^{1 / 2}=$ Average degree of dominance 
Table (11): Heterosis, inbreeding depression, heritability percentage in broad and narrow senses and expected genetic advance from selection for yield and yield components characters in four crosses of spring wheat under normal and water stress treatments.

\begin{tabular}{|c|c|c|c|c|c|c|c|c|}
\hline \multirow{2}{*}{ Character } & \multirow{2}{*}{ Cross } & \multirow{2}{*}{ Treat. } & \multicolumn{2}{|c|}{ Heterosis \% } & \multirow{2}{*}{$\begin{array}{l}\text { Inbreeding } \\
\text { depression \% }\end{array}$} & \multicolumn{2}{|c|}{$\begin{array}{l}\text { Heritability } \\
\text { percentage }\end{array}$} & \multirow{2}{*}{$\begin{array}{l}\text { Expected } \\
\text { genetic } \\
\text { advance }\end{array}$} \\
\hline & & & M.P & B.P & & $\mathbf{H}_{\text {b.s }} \%$ & $H_{n . s} \%$ & \\
\hline \multirow{8}{*}{$\begin{array}{l}\text { Plant } \\
\text { height }\end{array}$} & \multirow[t]{2}{*}{1} & $\mathrm{~N}$ & $5.26^{\star \star}$ & $-5.77^{* \star}$ & $7.68^{* \star}$ & 96.42 & 59.04 & 17.94 \\
\hline & & $S$ & $2.90^{* *}$ & $-8.45^{\star \star}$ & $4.30^{* *}$ & 97.21 & 91.01 & 33.20 \\
\hline & \multirow[t]{2}{*}{2} & $\mathrm{~N}$ & 1.00 & -0.56 & $2.47^{* *}$ & 91.55 & 51.91 & 11.20 \\
\hline & & $\mathrm{S}$ & $2.06^{\star \star}$ & -0.57 & $3.08^{\star \star}$ & 90.66 & 37.16 & 8.05 \\
\hline & \multirow[t]{2}{*}{3} & $\mathrm{~N}$ & $3.25^{\star \star}$ & $-6.99^{\star *}$ & $2.73^{*}$ & 98.39 & 98.39 & 36.83 \\
\hline & & $S$ & 1.20 & $-5.14^{\star \star}$ & $2.53^{*}$ & 96.13 & 72.23 & 27.43 \\
\hline & \multirow[t]{2}{*}{4} & $\mathrm{~N}$ & 1.22 & 0.35 & $3.50^{* *}$ & 90.32 & 50.68 & 9.74 \\
\hline & & $S$ & $2.49^{*}$ & -0.60 & 1.67 & 80.25 & 80.25 & 15.65 \\
\hline \multirow{8}{*}{$\begin{array}{l}\text { Spikes } \\
\text { number } \\
\text { plant }^{-1}\end{array}$} & \multirow[t]{2}{*}{$\overline{11}$} & $\bar{N}$ & $-21.88^{* \star}$ & $-32.45^{\star \star}$ & $5.17^{\star \star}$ & 59.46 & 57.22 & 40.94 \\
\hline & & $S$ & $-25.43^{\star *}$ & $-25.94^{* *}$ & $-40.28^{* \star}$ & 83.10 & 83.10 & 68.94 \\
\hline & \multirow[t]{2}{*}{2} & $\mathrm{~N}$ & $-18.74^{\star *}$ & $-29.03^{\star *}$ & $-7.08^{\star *}$ & 74.19 & 52.03 & 41.31 \\
\hline & & $\mathrm{S}$ & $-16.58^{* *}$ & $-24.57^{* *}$ & $-6.11^{\star *}$ & 66.48 & 14.53 & 10.70 \\
\hline & \multirow[t]{2}{*}{3} & $\mathrm{~N}$ & $-21.02^{* *}$ & $-31.87^{\star *}$ & -0.40 & 39.15 & 15.99 & 11.08 \\
\hline & & $S$ & $-9.93^{* *}$ & $-23.84^{\star *}$ & $-28.60^{* *}$ & 65.67 & 65.67 & 44.28 \\
\hline & \multirow[t]{2}{*}{4} & $\mathrm{~N}$ & $-6.24^{* *}$ & $-18.30^{* *}$ & 0.65 & 71.83 & 71.83 & 58.96 \\
\hline & & $\mathrm{S}$ & $-10.75^{\star \star}$ & $-30.10^{\star *}$ & $-22.05^{\star *}$ & 65.78 & 65.78 & 51.09 \\
\hline \multirow{8}{*}{$\begin{array}{l}\text { Grains } \\
\text { number } \\
\text { spike }^{-1}\end{array}$} & \multirow[t]{2}{*}{$\overline{11}$} & $\mathrm{~N}$ & $-5.67^{*}$ & $-11.99^{* *}$ & $7.53^{* *}$ & 67.69 & 23.34 & 13.99 \\
\hline & & $S$ & $6.85^{\star *}$ & -2.77 & $14.01^{* *}$ & 68.59 & 29.36 & 18.68 \\
\hline & \multirow[t]{2}{*}{2} & $\mathrm{~N}$ & 2.43 & -0.05 & 2.32 & 67.33 & 4.84 & 2.33 \\
\hline & & $\mathrm{S}$ & $-8.19^{\star *}$ & $-13.72^{\star *}$ & 1.89 & 59.62 & 6.20 & 3.10 \\
\hline & \multirow[t]{2}{*}{3} & $\mathrm{~N}$ & -3.17 & $-10.43^{\star *}$ & -1.08 & 77.67 & 77.67 & 47.74 \\
\hline & & $\mathrm{S}$ & 3.16 & $-7.25^{\star \star}$ & -0.43 & 65.95 & 16.70 & 9.46 \\
\hline & \multirow[t]{2}{*}{4} & $\mathrm{~N}$ & -1.42 & -4.67 & 20.39 & 80.58 & 68.89 & 52.80 \\
\hline & & $\mathrm{S}$ & $-28.54^{* *}$ & $-31.99^{\star *}$ & -12.69 & 73.93 & 69.99 & 50.87 \\
\hline \multirow{8}{*}{$\begin{array}{l}\text { 100-grain } \\
\text { weight }\end{array}$} & \multirow[t]{2}{*}{1} & $\mathrm{~N}$ & $-7.40^{* *}$ & $-15.74^{\star *}$ & $1.48^{* *}$ & 69.72 & 47.00 & 22.76 \\
\hline & & $\mathrm{S}$ & $19.58^{\star \star}$ & $6.39^{\star \star}$ & $18.36^{\star \star}$ & 55.43 & 5.68 & 3.03 \\
\hline & 2 & $\mathrm{~N}$ & $6.66^{\star \star}$ & $-2.29^{* *}$ & $6.23^{\star \star}$ & 53.34 & 24.26 & 6.91 \\
\hline & & $\mathrm{S}$ & $6.87^{* \star}$ & $-1.99^{\star *}$ & $3.61^{* \star}$ & 78.81 & 28.40 & 11.12 \\
\hline & 3 & $\mathrm{~N}$ & $6.69^{\star *}$ & -0.19 & $5.86^{* *}$ & 75.44 & 75.44 & 39.74 \\
\hline & & $\mathrm{S}$ & $11.75^{\star \star}$ & $5.48^{\star *}$ & $-5.33^{\star *}$ & 61.73 & 28.82 & 10.78 \\
\hline & 4 & $\mathrm{~N}$ & $14.27^{\star \star}$ & $7.65^{\star *}$ & $14.55^{\star \star}$ & 91.23 & 91.23 & 50.67 \\
\hline & & $\mathrm{S}$ & $13.83^{\star \star}$ & $10.99^{* *}$ & $8.81^{\star *}$ & 71.82 & 50.86 & 19.49 \\
\hline & 1 & $\mathrm{~N}$ & $-16.83^{* \star}$ & $-33.07^{* *}$ & -3.74 & 90.05 & 90.05 & 89.38 \\
\hline & & $\mathrm{S}$ & $-11.73^{\star *}$ & $-27.66^{\star *}$ & $-8.99^{\star \star}$ & 85.99 & 85.99 & 83.87 \\
\hline & 2 & $\mathrm{~N}$ & $-23.53^{\star \star}$ & $-27.31^{\star *}$ & $8.72^{\star \star}$ & 86.76 & 26.24 & 25.65 \\
\hline Grain yield & & $\mathrm{S}$ & $-19.54^{\star *}$ & $-21.9^{\star \star}$ & $-5.72^{\star \star}$ & 77.54 & 35.23 & 27.63 \\
\hline plant $^{-1}$ & 3 & $\mathrm{~N}$ & $10.51^{* *}$ & -3.50 & $17.37^{\star *}$ & 89.33 & 76.91 & 79.05 \\
\hline & & $\mathrm{S}$ & $40.99^{\star \star}$ & $19.53^{\star *}$ & $9.27^{\star \star}$ & 80.77 & 65.00 & 60.41 \\
\hline & 4 & $\mathrm{~N}$ & $-29.33^{\star *}$ & $-38.66^{\star *}$ & $21.33^{\star *}$ & 91.05 & 91.05 & 96.19 \\
\hline & & $\mathrm{S}$ & $-13.98^{* *}$ & $-36.68^{* *}$ & $-20.48^{* *}$ & 84.69 & 84.69 & 91.33 \\
\hline
\end{tabular}

Cross 1= Line 1 × Sakha 93

Cross 3 = Sakha $93 \times$ Gemmiza 9

$\mathrm{N}=$ Normal treatment
Cross 2 = Line $1 \times$ Sakha 94

Cross 4 = Sakha $94 \times$ Gemmiza 9

S = Water stress treatment 
Heritability estimate in narrow sense $\left(\mathrm{h}_{\mathrm{n} . \mathrm{s}}\right)$ for plant height had moderate to high percentages at all crosses under both water treatments; for spikes number plant ${ }^{-1}$ and grain yield plant ${ }^{-1}$ had moderate to high percentages at most cases under both water treatments. While, it was low for grains number spike-1 at most cases under both water treatments, and for 100-grain weight it was low at cross 1 , cross 3 under water stress treatment and cross 2 under both water treatments but it was moderate to high at remaining cases. These results are in agreement with those obtained by El-Hawary (2006), Ahmadi and Bajelan (2008) and ShehabEldeen (2008).

As shown in Table (11), the values for expected genetic advance $(\Delta \mathrm{g}$ $\%$ ) were found to be low for plant height at most cases under both water treatments. While, it was high for spikes number plant ${ }^{-1}$ and grain yield plant ${ }^{-1}$ at most cases under both water treatments. Also, it was found to be low to high for plant height, grains number spike ${ }^{-1}$ and 100 grains weight at most cases under both water treatments. These results are in general agreement with those obtained by Ahmed et al.(2007) and Aboshosha and hammad (2009).

\section{REFERENCES}

Abd El-Rahman, Magda E. and S. M. Hammad. (2009). Estimation of some genetic parameters for some agronomic characteristics in three crosses of bread wheat. J. Agric. Sci., Mansoura Univ., 34(2): 10911100.

Aboshosha, A.A.M. and S.M. Hammad (2009). Estimation of parameters for yield and yield components and some agronomic characters in two crosses of bread wheat (Triticum aestivum L.). J. Agric. Sci., Mansoura Univ., 34(5): 4293-4300.

Ahmadi, H. and B. Bajelan (2008). Heritability of drought tolerance in wheat. American Eurasian J. of Agric. and Environm. Sci., 3(4): 632-635.

Ahmed, N.; M. A. Chowdhry; I. Khaliqc and M. Maekawaa (2007). The inheritance of yield and yield components of five wheat hybrid populations under drought conditions. Indonesian J. Agric. Sci., 8(2): 53-57.

Allard, A.M. (1999). Principles of plant breeding. $2^{\text {nd }}$ ed. Joh Wily and Sons. N.Y., USA.

Blum, A. (1988). Plant breeding for stress environments. CRC Press, Florida. p 212.

El-Hag, A.A. (2006). Estimation of genetic parameters for earliness and some agronomic characters in three crosses of bread wheat, (Triticum aestivum L.). J. Agric. Sci., Mansoura Univ., 31(7): 4271-4280.

El-Hawary, M.N.A. (2006). Breeding for drought tolerance in bread wheat. M.Sc. Thesis, Fac. of Agric, Mansoura Univ., Egypt.

Farhat, W.Z.E.(2005). Genetical studies on drought tolerance in bread wheat (Triticum aestivum L). M.Sc. Thesis, Fac. of Agric., Tanta Univ., Egypt.

Golestani, S.A. and M.T. Assad (1998). Evaluation of four screening techniques for drought resistance and their relationship to yield reduction in wheat. Euphytica, 103:293-299. 
Hall, A.E., 1993. Is dehydration tolerance relevant to genotypic differences in leaf senescence and crop adaptation to dry environments? In: T.J. Close and Bray, E.A., (Eds.), Plant Responses to cellular Dehydration during environmental stress. pp. 1-10.

Jinks, J. L. and R.M. Jones (1958). Estimation of the components of heterosis. Genetics, 43:223-234.

Kandic, V.; D. Dodig; M. Jovic; B. Nikolic and S. Prodanovic (2009). The importance of physiological characters in wheat breeding under irrigation and drought stress. Genetica, 41(1): 11-20.

Mather, K. and J.K. Jinks (1982). Biometrical genetics. Great Br. Univ. Press, $3^{\text {rd }}$ ed.

Misra S.C.; V.S. Rao; R.N. Dixit; V.D. Surve and V.P. Patil (1994). Genetic control of yield and its components in bread wheat. Indian J. of Genetics 54:77-82.

Rosielle, A.A. and J. Hambling (1981). Theoretical aspects of selection for yield in stress and non-stress environments. Crop Sci., 21:943-946.

ShehabEldeen, M.T.M. (2008). Genetic studies on earliness and drought tolerance in bread wheat. M.Sc. Thesis, Fac. of Agric., Cairo, Univ., Egypt.

Tahmasebi, S.; M. Khodambashi and A. Rezai (2007). Estimation of genetic parameters for grain yield and related traits in wheat using diallel analysis under optimum and moisture stress conditions. J. Sci. \& Technol. Agric. \& Natur. Resour., 11(1A): 229-241.

Tammam A.M. (2005). Generation mean analysis in bread wheat under different environmental conditions. Minufiya J. Agric. Res. 30 (3) : 937956.

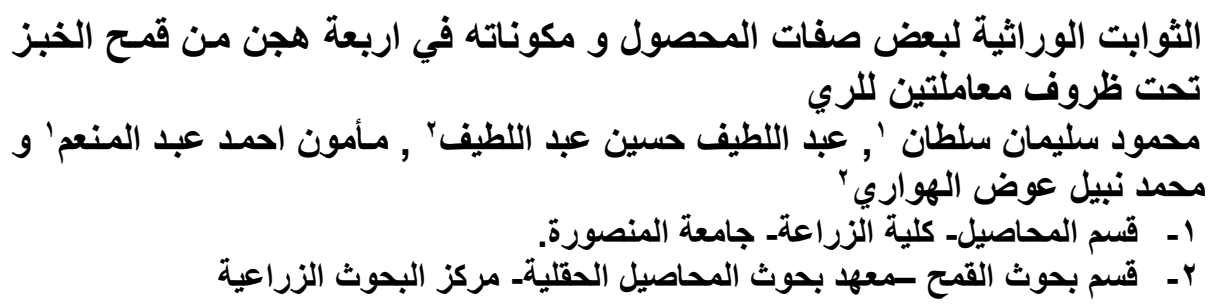

تم استخدام ست عشائر لأربعة هجن من قمَح الخبز

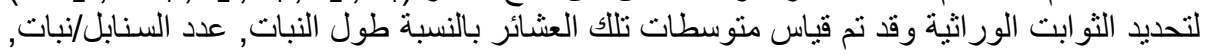

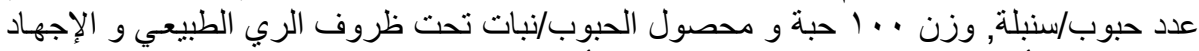

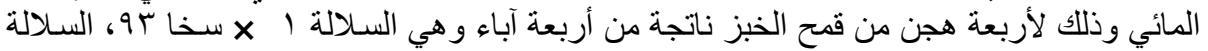

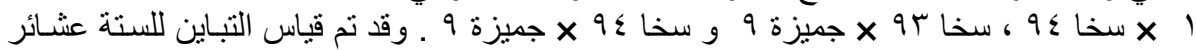

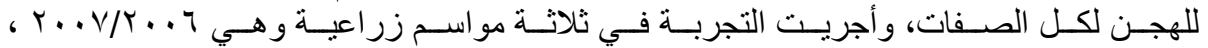

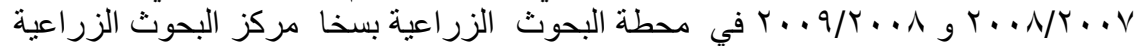

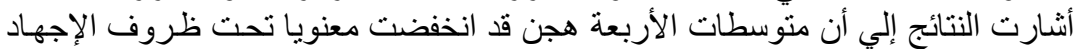

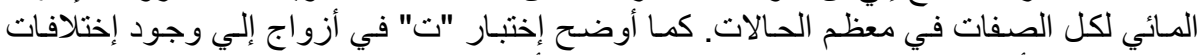

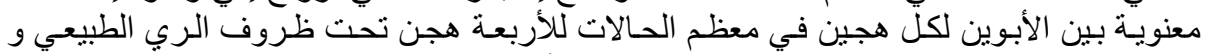

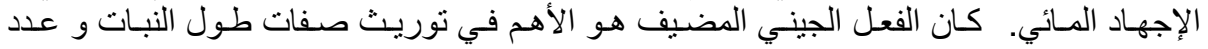




\section{Sultan, M. S. et al.}

سنابل/نبات في حين كان الفعل الجيني المضيف, السيادي و التفوقي لهم الأهمية في توريث صفات

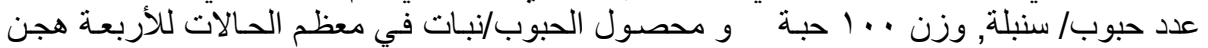

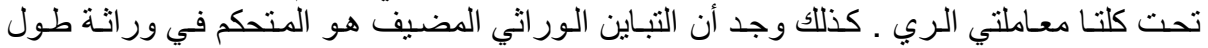

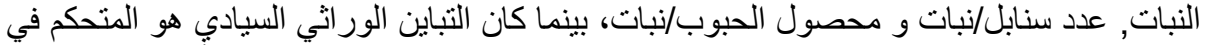

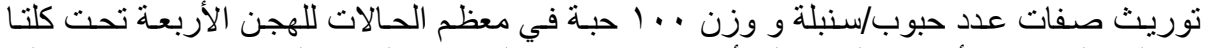

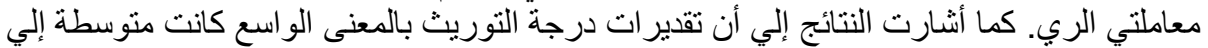

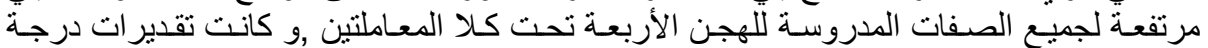

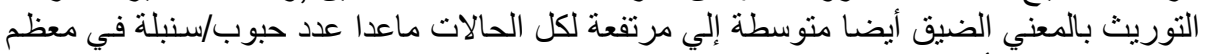

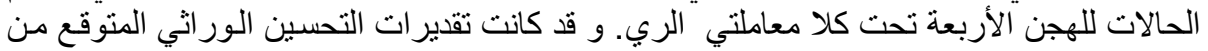

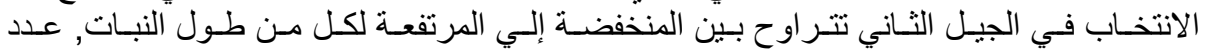

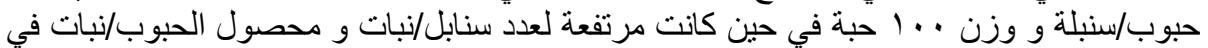
معظم الحالات للهجن الأربعة تحت كلتا معاملتي الري.

كلية الزراعة - جامعة المنصورة قام بتحكيم البحث مركز البحوث الزراعية

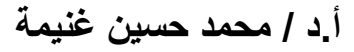
أ.د / تاج الدين محمد شهاب الدين 
J. Plant Production, Mansoura Univ., Vol. 2 (2): 351 - 366, 2011

Table (8): Types of gene action using generation means for plant height and spikes number plant ${ }^{-1}$ characters in four crosses of spring wheat under normal and water stress treatments.

\begin{tabular}{|c|c|c|c|c|c|c|c|c|c|c|c|}
\hline Character & Cross & Treat. & A & B & C & m & d & $\mathbf{h}$ & $\mathbf{i}$ & j & $\mathrm{I}$ \\
\hline \multirow{8}{*}{$\begin{array}{l}\text { Plant } \\
\text { height }\end{array}$} & \multirow{2}{*}{1} & $\bar{N}$ & -0.75 & -3.83 & $-23.14^{\star \star}$ & $87.53^{\star *} \pm 4.72$ & $12.42^{\star *} \pm 0.40$ & $38.11^{* \star} \pm 12.01$ & $18.55^{\star \star} \pm 4.7$ & $3.08 \pm 3.39$ & $-13.97 \pm 7.49$ \\
\hline & & $\mathrm{S}$ & -4.00 & -0.67 & $-12.30^{* \star}$ & $95.86^{* *} \pm 5.27$ & $12.83^{* *} \pm 0.41$ & $13.61 \pm 13.09$ & $7.64 \pm 5.26$ & $-3.33 \pm 3.54$ & $-2.97 \pm 8.05$ \\
\hline & \multirow{2}{*}{2} & $\mathrm{~N}$ & $-9.0^{* *}$ & $-7.50^{\star \star}$ & $-9.30^{* *}$ & $123.86^{* *} \pm 3.80$ & $1.83^{\star \star} \pm 0.50$ & $-29.73^{* \star} \pm 9.75$ & $-7.2 \pm 3.77$ & $-1.5 \pm 2.86$ & $23.7^{\star \star} \pm 6.12$ \\
\hline & & $S$ & $-9.92^{\star \star}$ & 0.75 & $-9.58^{* *}$ & $112.92^{\star *} \pm 3.82$ & $3.00^{* *} \pm 0.52$ & $-6.02 \pm 9.88$ & $0.41 \pm 3.78$ & $-10.67^{\star \star} \pm 2.94$ & $8.76 \pm 6.24$ \\
\hline & \multirow{2}{*}{3} & $\mathrm{~N}$ & 1.83 & $-10.33^{* *}$ & -5.05 & $108.7^{\star *} \pm 5.46$ & $-11.58^{\star \star} \pm 0.30$ & $-11.99 \pm 13.37$ & $-3.45 \pm 5.45$ & $12.17^{\star \star} \pm 3.49$ & $11.95 \pm 8.15$ \\
\hline & & S & 2.25 & -1.50 & -7.63 & $96.97^{\star \star} \pm 0.45$ & $-6.33^{\star \star} \pm 0.46$ & $1.15 \pm 0.73$ & $\square$ & $\square$ & $\square$ \\
\hline & \multirow{2}{*}{4} & $\mathrm{~N}$ & $-11.99^{\star \star}$ & $-10.82^{\star \star}$ & $-13.60^{* *}$ & $125.05^{\star *} \pm 3.34$ & $-1.00 * \pm 0.43$ & $-39.83^{* \star} \pm 8.57$ & $-9.21^{* *} \pm 3.31$ & $-1.17 \pm 2.51$ & $32.03^{\star \star} \pm 5.44$ \\
\hline & & $S$ & -2.17 & -3.00 & -2.00 & $106.61^{* \star} \pm 0.51$ & $3.44^{\star \star} \pm 0.49$ & $2.16^{*} \pm 0.98$ & $\square$ & $\square$ & $\square$ \\
\hline \multirow{8}{*}{$\begin{array}{l}\text { Spikes } \\
\text { number } \\
\text { plant }^{-1}\end{array}$} & \multirow{2}{*}{1} & $\mathrm{~N}$ & $-7.73^{\star \star}$ & $-16.15^{\star \star}$ & $-8.14^{\star *}$ & $45.23^{* *} \pm 2.69$ & $-4.62^{\star \star} \pm 0.68$ & $-61.82^{* *} \pm 7.01$ & $-15.75^{\star \star} \pm 2.61$ & $8.42^{\star \star} \pm 2.28$ & $39.63^{\star \star} \pm 4.79$ \\
\hline & & $S$ & $-5.03^{\star *}$ & -0.15 & $15.30^{* *}$ & $42.57^{\star \star} \pm 2.66$ & $-0.15 \pm 0.53$ & $-51.77^{* \star} \pm 6.55$ & $-20.48^{* \star} \pm 2.6$ & $-4.88^{\star} \pm 1.93$ & $25.67^{* \star} \pm 4.12$ \\
\hline & \multirow{2}{*}{2} & $\mathrm{~N}$ & $-5.57^{\star \star}$ & $-7.20^{\star \star}$ & -4.21 & $37.64^{\star *} \pm 3.12$ & $-4.22^{\star \star} \pm 0.63$ & $-35.33^{\star \star} \pm 8.07$ & $-8.56^{\star \star} \pm 3.05$ & $1.63 \pm 2.51$ & $21.32^{\star \star} \pm 5.33$ \\
\hline & & $S$ & -2.92 & $-4.43^{*}$ & -3.13 & $28.76^{\star *} \pm 2.65$ & $-2.60^{\star \star} \pm 0.62$ & $-19.86^{\star \star} \pm 7.02$ & $-4.22 \pm 2.58$ & $1.52 \pm 2.3$ & $11.57^{\star} \pm 4.61$ \\
\hline & \multirow{2}{*}{3} & $\mathrm{~N}$ & $-11.76^{\star \star}$ & $-6.90^{* *}$ & $-11.99^{\star \star}$ & $36.08^{* *} \pm 2.72$ & $4.68^{\star \star} \pm 0.79$ & $-38.17^{* \star} \pm 7.27$ & $-6.67^{\star} \pm 2.6$ & $-4.86 \pm 2.51$ & $25.32^{\star \star} \pm 5.06$ \\
\hline & & $S$ & -0.45 & 2.73 & $15.64^{\star \star}$ & $32.15^{\star \star} \pm 2.21$ & $3.43^{* *} \pm 0.57$ & $-26.29^{* *} \pm 5.67$ & $-13.35^{\star *} \pm 2.14$ & $-3.18 \pm 1.85$ & $11.07^{\star \star} \pm 3.72$ \\
\hline & \multirow{2}{*}{4} & $\mathrm{~N}$ & $-4.94^{\star \star}$ & $-8.96^{\star \star}$ & -4.33 & $38.59^{* *} \pm 3.33$ & $4.28^{\star \star} \pm 0.75$ & $-34.85^{\star \star} \pm 8.52$ & $-9.57^{\star \star} \pm 3.24$ & $4.02 \pm 2.67$ & $23.47^{\star \star} \pm 5.61$ \\
\hline & & $S$ & -1.62 & $7.50^{* *}$ & $12.16^{\star \star}$ & $27.53^{\star *} \pm 2.73$ & $5.88^{* *} \pm 0.66$ & $-8.95 \pm 7.03$ & $-6.28^{\star} \pm 2.65$ & $-9.12^{\star \star} \pm 2.25$ & $0.39 \pm 4.71$ \\
\hline
\end{tabular}

${ }^{*},{ }^{* *}=$ significant at 0.05 and 0.01 levels of probability, respectively.

$\mathrm{N}$ = Normal treatment $\mathrm{S}=$ water stress treatment

$N=$ Normal treatment $\quad S=$ water stress treatment

Cross $1=$ Line $1 \times$ Sakha 93

$m=$ mean effect

Cross 2 = Line $1 \times$ Sakha 94

Cross $3=$ Sakha $93 \times$ Gemmiza 9

Cross 4 = Sakha $94 \times$ Gemmiza 9

$\mathrm{i}=$ additive $\times$ additive effect

$d=$ additive effect

$h=$ dominance effete

I= dominance $\times$ dominance effect 
Table (9): Types of gene action using generation means for grains number spike-1, 100-grain weight and grain yield plant ${ }^{-1}$ characters in four crosses of spring wheat under normal and water stress treatments.

\begin{tabular}{|c|c|c|c|c|c|c|c|c|c|c|c|}
\hline Character & Cross & Treat. & A & $B$ & C & $\mathbf{m}$ & $\mathrm{d}$ & h & $\mathbf{i}$ & 1 & $I$ \\
\hline \multirow{8}{*}{ 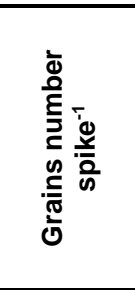 } & \multirow{2}{*}{1} & $\mathrm{~N}$ & $-28.15^{\star \star}$ & -5.85 & $-26.28^{\star \star}$ & $73.84^{\star \star} \pm 5.63$ & $4.75^{\star \star} \pm 1.21$ & $-53.2^{\star \star} \pm 14.84$ & $-7.72 \pm 5.5$ & $-22.3^{\star \star} \pm 4.74$ & $41.72^{\star \star} \pm 9.95$ \\
\hline & & $\mathrm{S}$ & $-16.20^{* *}$ & $-21.22^{\star \star}$ & $-27.84^{\star \star}$ & $69.87^{\star \star} \pm 5.69$ & $5.97^{\star \star} \pm 1.21$ & $-52.43^{\star \star} \pm 14.94$ & $-9.57 \pm 5.56$ & $5.02 \pm 4.75$ & $46.99^{\star \star} \pm 10.00$ \\
\hline & \multirow{2}{*}{2} & $\mathrm{~N}$ & $-24.63^{\star *}$ & $-9.78^{\star *}$ & -3.22 & $100.35^{\star *} \pm 5.58$ & $1.72 \pm 1.19$ & $-95.14^{\star *} \pm 14.81$ & $-31.20^{\star *} \pm 5.45$ & $-14.85^{\star \star} \pm 4.76$ & $65.62^{\star \star} \pm 9.89$ \\
\hline & & $\mathrm{S}$ & $-12.52^{* *}$ & $-24.92^{\star *}$ & $-16.52^{* *}$ & $91.71^{* *} \pm 5.37$ & $-4.53^{\star \star} \pm 1.27$ & $-85.06^{\star \star} \pm 14.29$ & $-20.91^{* *} \pm 5.21$ & $12.4^{\star \star} \pm 4.69$ & $58.35^{\star \star} \pm 9.66$ \\
\hline & \multirow[b]{2}{*}{3} & $\mathrm{~N}$ & -4.15 & $-10.09^{\star \star}$ & -1.45 & $79.58^{\star \star} \pm 5.84$ & $-5.42^{* \star} \pm 1.18$ & $-41.96^{* *} \pm 14.74$ & $-12.80^{*} \pm 5.72$ & $5.94 \pm 4.45$ & $27.04^{\star *} \pm 9.63$ \\
\hline & & $\mathrm{S}$ & -1.95 & $-11.18^{\star \star}$ & 4.95 & $79.28^{\star \star} \pm 5.92$ & $-6.87^{\star \star} \pm 1.31$ & $-47.36^{\star *} \pm 15.66$ & $-18.08^{\star \star} \pm 5.77$ & $9.23 \pm 5.05$ & $31.21^{\star *} \pm 10.47$ \\
\hline & \multirow{2}{*}{4} & $\mathrm{~N}$ & -0.49 & $-17.83^{\star \star}$ & $-58.11^{* *}$ & $30.03^{* \star} \pm 6.30$ & $-2.38^{*} \pm 1.16$ & $60.27^{\star \star} \pm 16.09$ & $39.79^{\star \star} \pm 6.19$ & $17.33^{\star \star} \pm 4.85$ & $-21.47^{*} \pm 10.44$ \\
\hline & & $\mathrm{S}$ & -5.45 & -3.5 & $-14.94^{*}$ & $65.71^{\star \star} \pm 6.32$ & $3.63^{* *} \pm 1.37$ & $-17.45 \pm 16.2$ & $5.99 \pm 6.17$ & $-1.95 \pm 5.04$ & $2.97 \pm 10.63$ \\
\hline \multirow{8}{*}{ 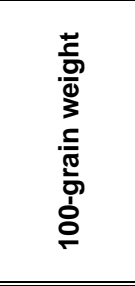 } & \multirow[b]{2}{*}{1} & $\mathrm{~N}$ & \begin{tabular}{|l|}
$-1.00^{* *}$ \\
\end{tabular} & $0.58^{\star \star}$ & $-0.94^{* *}$ & $4.12^{* \star} \pm 0.32$ & $0.46^{* *} \pm 0.07$ & $0.27 \pm 0.84$ & $0.52 \pm 0.31$ & $-1.58^{\star \star} \pm 0.26$ & $-0.10 \pm 0.56$ \\
\hline & & $\mathrm{S}$ & -0.26 & -0.24 & $-2.15^{\star \star}$ & $2.77^{\star *} \pm 0.38$ & $0.55^{\star \star} \pm 0.07$ & $3.66^{\star \star} \pm 1.03$ & $1.65^{\star \star} \pm 0.38$ & $-0.02 \pm 0.32$ & $-1.15 \pm 0.74$ \\
\hline & \multirow{2}{*}{2} & $\mathrm{~N}$ & 0.14 & $0.38^{* \star}$ & $-0.62^{* *}$ & $3.53^{\star \star} \pm 0.22$ & $0.43^{* *} \pm 0.06$ & $3.11^{\star *} \pm 0.58$ & $1.14^{\star *} \pm 0.21$ & $-0.23 \pm 0.2$ & $-1.66^{\star \star} \pm 0.39$ \\
\hline & & $\mathrm{S}$ & 0.03 & 0.12 & -0.08 & $4.55^{\star \star} \pm 0.04$ & $0.40^{* *} \pm 0.04$ & $0.32^{\star *} \pm 0.09$ & $\square$ & $\square$ & $\square$ \\
\hline & \multirow[b]{2}{*}{3} & $\mathrm{~N}$ & $\left|-1.25^{\star *}\right|$ & $-1.70^{\star *}$ & -0.52 & $6.91^{\star \star} \pm 0.34$ & $-0.31^{\star \star} \pm 0.06$ & $-7.49^{\star \star} \pm 0.85$ & $-2.42^{\star *} \pm 0.33$ & $0.45 \pm 0.24$ & $5.37^{\star \star} \pm 0.58$ \\
\hline & & $\mathrm{S}$ & 0.21 & $0.64^{* *}$ & $1.95^{* *}$ & $5.21^{* *} \pm 0.29$ & $-0.24^{* \star} \pm 0.07$ & $-0.87 \pm 0.77$ & $-1.10^{* *} \pm 0.29$ & $-0.43 \pm 0.25$ & $0.25 \pm 0.52$ \\
\hline & \multirow[b]{2}{*}{4} & $\mathrm{~N}$ & -0.04 & -0.24 & $-1.72^{\star \star}$ & $3.08^{\star \star} \pm 0.33$ & $-0.28^{\star \star} \pm 0.05$ & $3.26^{\star \star} \pm 0.78$ & $1.44^{* *} \pm 0.32$ & $0.2 \pm 0.21$ & $-1.17^{\star} \pm 0.48$ \\
\hline & & $S$ & 0.04 & $-0.62^{* \star}$ & -0.53 & $4.30^{\star \star} \pm 0.26$ & $-0.11^{*} \pm 0.05$ & $-0.11 \pm 0.68$ & $-0.05 \pm 0.26$ & $0.66^{* \star} \pm 0.21$ & $0.64 \pm 0.46$ \\
\hline \multirow{8}{*}{ 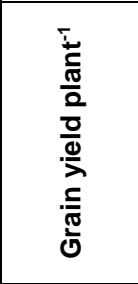 } & \multirow[b]{2}{*}{1} & $\mathrm{~N}$ & $-30.77^{\star *}$ & -7.11 & -12.11 & $82.83^{* \star} \pm 6.97$ & $13.85^{* *} \pm 0.86$ & $-99.01^{* \star} \pm 17.4$ & $-25.76^{\star *} \pm 6.91$ & $-23.66^{\star *} \pm 4.84$ & $63.64^{\star \star} \pm 11.07$ \\
\hline & & $\mathrm{S}$ & $-25.65^{\star *}$ & $-14.44^{\star \star}$ & 4.43 & $98.11^{* *} \pm 6.85$ & $11.80^{\star *} \pm 1.18$ & $-135.39^{\star *} \pm 16.73$ & $-44.51^{* *} \pm 6.74$ & $-11.21^{\star} \pm 4.71$ & $84.59^{\star *} \pm 10.57$ \\
\hline & \multirow{2}{*}{2} & $\mathrm{~N}$ & $-21.54^{* *}$ & $-22.02^{\star *}$ & $-55.17^{\star *}$ & $63.20^{* \star} \pm 8.17$ & $-3.89^{\star \star} \pm 1.16$ & $-37.94 \pm 21.31$ & $11.61 \pm 8.08$ & $0.48 \pm 6.4$ & $31.95^{\star \star} \pm 13.72$ \\
\hline & & $\mathrm{s}$ & $-25.03^{* *}$ & $-28.17^{\star *}$ & $-12.87^{*}$ & $103.81^{\star \star} \pm 6.73$ & $1.92 \pm 1.24$ & $-146.27^{* \star} \pm 17.57$ & $-40.33^{\star \star} \pm 6.62$ & $3.14 \pm 5.43$ & $93.53^{\star \star} \pm 11.54$ \\
\hline & \multirow{2}{*}{3} & $\mathrm{~N}$ & $-16.00^{\star *} \mid$ & $-25.30^{\star \star}$ & $-28.21^{\star \star}$ & $63.66^{\star \star} \pm 6.94$ & $-7.34^{\star \star} \pm 0.83$ & $-62.17^{\star \star} \pm 17.55$ & $-13.09 \pm 6.89$ & $9.3 \pm 4.96$ & $54.39^{\star \star} \pm 11.28$ \\
\hline & & $S$ & -1.41 & $-11.61^{* *}$ & 10.52 & $58.97^{\star \star} \pm 6.35$ & $6.36^{* \star} \pm 1.09$ & $-45.58^{\star *} \pm 16.26$ & $-23.54^{\star *} \pm 6.25$ & $10.2^{*} \pm 4.85$ & $36.56^{\star \star} \pm 10.66$ \\
\hline & & $\mathrm{N}$ & $-26.02^{\star *}$ & $-19.90^{\star \star}$ & 1.12 & $115.35^{\star \star} \pm 8.26$ & $10.40^{\star \star} \pm 1.14$ & $-160.04^{\star *} \pm 19.96$ & $-47.04^{\star *} \pm 8.18$ & $-6.13 \pm 5.33$ & $92.97^{\star *} \pm 12.38$ \\
\hline & & $\mathrm{S}$ & $-13.08^{* *}$ & $12.80^{* *}$ & $19.26^{* *}$ & $64.85^{\star \star} \pm 7.04$ & $16.24^{* *} \pm 1.15$ & $-45.68^{* *} \pm 17.42$ & $-19.53^{* *} \pm 6.94$ & $-25.89^{\star \star} \pm 4.92$ & $19.81 \pm 11.23$ \\
\hline
\end{tabular}

** = significant at 0.05 and 0.01 levels of probability, respectively. $\mathrm{N}=$ Normal treatment

Cross $1=$ Line $1 \times$ Sakha 93

$m=$ mean effect

Cross 2 = Line $1 \times$ Sakha 94

$\mathrm{i}=$ additive $\times$ additive effect $\mathrm{j}=$ additive $\times$ dominance effect

$\mathbf{S}=$ water stress treatment

Cross 3 = Sakha $93 \times$ Gemmiza 9 Cross 4 = Sakha $94 \times$ Gemmiza 9 $\mathrm{h}=$ dominance effete

I= dominance $\times$ dominance effect 